\title{
From Medieval Mnemonics to a Social Construction of Memory
}

\author{
Thoughts on Some Early European Conceptualizations \\ of Memory, Morality, and Consciousness
}

\author{
NOEL PACKARD \\ New School University \\ CHRISTOPHER CHEN \\ University of California-Berkeley
}

\begin{abstract}
How did human memory activity, conceived of as an activity that helped bring a person closer to God, become affiliated with early sociological conceptualizations of a social construction of reality? This article explores one way of answering this question by considering some social conceptions of human memory from medieval times to modernity. In the Middle Ages, a good memory was an important characteristic of the most esteemed scholars. Rhetoric was enhanced through mnemotechniques. Memory as practiced activity complemented early theological concepts of self-consciousness, or "being" closer to God, and morality and complemented early interpretations of contract law, casuistry, and jurisprudence. These concepts changed when religious belief, educational, and legal systems changed to meet the needs of a modern, capitalistic, and secular society. Capitalism facilitated the development of memory in commodity form, and human memory was claimed from metaphysical discourse as an object of scientific study by sociologists Emile Durkheim and Maurice Halbwachs.
\end{abstract}

Keywords: memory; morality; consciousness; casuistry; forgetting

This article presents one answer to the question, "How did early sociologists come to claim the study of memory as sociological activity?" The discussion begins with the social practices of memorization used in the Middle Ages and ends where theories about collective memory were posited by early sociologists such as Maurice Halbwachs and later, George Mead. Halbwachs and Mead both studied the work of metaphysicians such as Leibniz and Bergson. It appears that medieval and later metaphysical ideas and practices regarding trained human memory as critical for human goodness were incorporated into sociology from its beginning.

AMERICAN BEHAVIORAL SCIENTIST, Vol. 48 No. 10, June 2005 1297-1319

DOI: $10.1177 / 0002764205277010$

(C) 2005 Sage Publications 
The medieval practice of studying philosophy as a way to know oneself and the medieval problem of rhetorically establishing one's relationship to a subject took different forms in theories of human religion and consciousness. Similarly, human memory and memorization have also been interpreted and applied differently in historical and contemporary conceptualizations of self. This article compares some medieval societal concepts of self-knowledge to early sociological conceptions of self and consciousness. It considers the relationship that social conceptions of memory, memorization, and mnemonics have to early sociological theories about collective memory and their historical and social contexts. The article considers interpretations of the self, conscience, religion, and morality and their historically changing relationships to one another.

\section{SELF-KNOWLEDGE, MEMORY, AND MORALITY IN MEDIEVAL SOCIETY}

In the 12th century, Platonism was taught at an institute of St. Victor's monastery outside of Paris. According to those who studied at St. Victor's, scholarly study was internal self-reflection regarding the obscured connections between self and nature. The learned human was not a walking repository of facts but rather, someone who distinguished details from the whole and dialogued with other scholars by use of rhetoric and Aristotelian rules of logic.

Memory and discourse as used in medieval philosophy and pedagogy were instrumental to and predecessors of objective thinking as advanced by Abelard, Augustine, and others who wished to make the "assent to articles of faith something more than blind acceptance to authority" (Piltz, 1981, pp. 40-41). Christian philosophy relied heavily on faith and tradition, whereas Abelard's evaluative, reflective, and objective approach did not entail the scholar having first decided his personal relationship to that which was to be interpreted, thereby revolutionizing the dialectic conception of human agency and morality (Nelson, 1965, p. 64; Nelson, 1981, pp. 34-66). Thus, solutions to problems were no longer the exclusive domain of authorities with access to divinely inspired truth (Piltz, 1981, p. 83).

The 12th and 13th centuries are interpreted today as a time of "movement from a neo-Platonist matter/spirit dualism, influenced profoundly by Augustine (though not identical with his thought), to an Aristotelian hylemorphism articulated most successfully by Thomas Aquinas" (Carruthers, 1990/1996, p. 13). Medieval belief systems incorporated a hierarchical vision of the world in which all things, material and nonmaterial, were categorized according to their degree of perfection (with God being perfection). All other material or nonmaterial entities were endowed with or receivers of various degrees of "being" or "light" from God. 
This conceptual totality of God as One, or the "Good and Eternal Light," greatly influenced philosophers such as Thomas Aquinas and medieval society in general (where such notions provided further ideological justification for the patriarchal family in particular and for social hierarchies in general). In the social sphere, being and morality both became rarely obtainable forms of perfection, in contrast to the concept of evil signified by a lack of goodness or activity-in short, a lack of being. According to this Dionysian belief system, evil became a form of exhausted or dead matter (Piltz, 1981, pp. 26-27). That which lacked goodness (being and perfection) could receive it from God, but only to the extent that an entity's receptivity would allow; receivers were responsible themselves for the amount of goodness they received from God. In his book Ecstasies, Carlos Ginzburg (1989/1992) considered how, historically, Church inquisitors persecuted supposedly culturally distant witches but simultaneously helped to crystallize, or contributed to, the "inner coherence" (p. 78; see also Ginzburg, 1981, p. 277; Sider \& Smith, 1997, p. 4) of the witch sects, simultaneously strengthening their own inner coherence.

A totalizing conception of God as the giver of being to that which is "not being" infused medieval society with a sense of nature and goodness as all responsible and all powerful, whereas humans needed to practice their ability to be increasingly good. If goodness meant being active in the world (rather than dead organic matter, which was evil), then activity such as warfare or torture might be viewed as good, moral, life-affirming activity that might bring a conqueror closer to God and perfection. Contrarily, those killed in warfare or torture (being dead matter) would have had a total lack of being or goodness. This view of life as a futile striving for perfection in the hierarchical scheme of perfection invariably fostered a sense of life as a "round of sin and penance" (Nelson, 1965, p. 71). In addition, it created a society in which hurting people was justified as a matter of "saving souls" and elevating the "soul" of the person who hurt others in the service of God.

\section{MEMORIA AND MNEMONICS IN MEDIEVAL SOCIETY}

Discussion about historical human memorization practices and social values attached to such behavior owes tribute to the work of Frances A. Yates (1966/ 1974) in her acclaimed book The Art of Memory. The book is an analysis of the ancient history of the human activity of training memory or as the Greeks called it, mnemosyne. Yates began her history of mnemosyne in a quest to understand Bruno's works on memory after writing Giordano Bruno and the Hermetic Tradition (Yates, 1964/1991). The quest led her to a comparison of Bruno and Leibniz's conceptualizations of the art of memory as a foundation for some of humankind's greatest aspirations, such as love, art, magic, mathematics and 
ultimately the contemporary project of scientific method. In The Art of Memory, Yates (1966/1974) wrote,

Mysticism and philanthropy are bound up with the encyclopaedia and the universal calculus. When we think of this side of Leibniz, the comparison with Bruno is again striking. The religion of Love, Art, Magic, and Mathesis was hidden in the Seals of Memory. A religion of love and general philanthropy is to be made manifest, or brought about, through the universal calculus. If we delete Magic, substitute genuine mathematics for Mathesis, understand Art as the calculus, and retain Love, the Leibnizian aspirations seem to approximate strikingly closely—though in a seventeenth-century transformation-to those of Bruno. (p. 387)

In keeping with the dynamic changes and conflicts of the Middle Ages, traditional faith-based medieval philosophy was challenged in 1128 by "new" logic, which was actually old Aristotelian logic newly translated from Greek to Latin. Both new and old logic were indebted to earlier medieval methods of memorization, or memoria, as the academic discipline of recalling textual knowledge of antiquity (itself an acknowledgement of progress beyond antiquity). In praise of the "giants of antiquity," the famous quote of Bernard of the Cathedral School of Chartres reflects this self-awareness:

We are dwarves sitting on the shoulders of giants. We can see more than they can and further, not because our eyes are clearer or our bodies taller, but because they arose and lifted us up into the heights. (Piltz, 1981, p. 41)

In addition to serving as a method for medieval subjects to enter into a conversation with the past, memoria was an honorable mental discipline in a world where books were scarce and rhetorical dialogue was instrumental in teaching and learning the catechism. In The Book of Memory, Mary Carruthers (1990/ 1996) wrote,

Training the memory was much more than a matter of providing oneself with the means to compose and converse intelligently when books were not readily at hand, for it was in trained memory that one built character, judgment, citizenship, and piety. (p. 9)

The higher levels of instruction in the catechism retain the question and answer format but with more of an emphasis on creative responses based on the assimilated knowledge. In her book devoted to descriptions of medieval memorytraining techniques and mnemonics, Carruthers underscored the dialectical essence of memoria:

The choice to train one's memory or not, for the ancients and medievals, was not a choice dictated by convenience: it was a matter of ethics. A person without a memory, if such a thing could be, would be a person without moral character and, in a basic sense, without humanity. Memoria refers not to how something is communicated, but to what happens once one has received it, to the interactive process of 
familiarizing — or textualizing — which occurs between oneself and other words in memory. (p. 13)

"Proper preparation of material, rigid order, and complete concentration," Carruthers wrote, "are the requirements which Thomas Aquinas himself defines in his discourses on trained memory, and as we will see, are continuously emphasized in all ancient and medieval mnemonic practices" (p. 8). A welltrained memory was not just a practical gimmick for parroting politically correct answers but also a moral force, a virtue, and condition of prudence that was coextensive with wisdom and knowledge (Carruthers, 1990/1996, p. 71).

Torture, being very much a part of the Middle Ages, was not only inflicted as punishment but also illustrated in lesson books to ensure that children memorized certain rules. For example an illustration of a man with spears representing height, width, and length, running through parts of his body, was used to "remind" children of the equation that yields the volume of a body (height $\times$ length $\times$ width $)$ (Piltz, 1981, p. 47). Besides using Aquinas's technique of concentration and rigid order, children's lesson-book illustrations of fearful forms of human suffering were used to remind them of what was in store for those who deviated from Christian doctrine.

But this aspect of punishment was absorbed into a larger meditative framework, part of a trinity of qualities that theologians such as St. Thierry, David of Augsburg, and St. Bonaventure used to achieve spiritual perfection or union with God. In his essay "The Way to Religious Perfection According to St. Bonaventure's De triplici via," Phillips (1955) observed of St. Bonaventure's book, "Many modern scholars have discussed the De triplici via from the point of view more in harmony with the outlook of St. Thomas than with that of St. Bonaventure" (p. 32). Phillips argued that although St. Bonaventure's project was marked by Platonic conceptions, it viewed

union chiefly in terms of an inner ethical transformation of experience rather than in terms of a cognitive orientation of the soul toward a higher reality. . . . For St. Bonaventure, as for St. Augustine, the very meaning of mystical union lay in a realm somewhat different from that frequently associated with contemplative "vision." (p. 33)

Phillips succinctly rearticulated the trinity described in De triplici via in the following way:

If the De triplici via is examined in the light of Augustinian ethics, there is ample evidence that the idea of a threefold way was intended not as an analysis of successive steps toward contemplation but as a description of the correlative aspects of deep and earnest spiritual effort. Memory must turn from evil, the true must be understood, and affection must draw the soul toward the good if spiritual effort is to be efficacious. This means that the De triplici via is not essentially a survey of the beginning, middle, and end of activity directed toward contemplation. It is a 
treatise on systematic use of meditation to achieve an ethical reorientation of inner life. (p. 33)

\section{CONSCIOUSNESS LIBERATED: THE REFORMATION}

Martin Luther (1483-1546) renewed Christian liberty by asserting fundamentally that the free human possessed his or her own free conscience. Averse to the programmatic medieval integration of conscience, casuistry, and the cure for souls, Luther burned the books of canon law and the "cases of conscience" of Angelus Carletus de Clavasio. Spiritual direction was to be found not in the socially constructed world of casuistry but instead, in the faith of the individual. A system of casuistry that made conscience and morality operative in the world could not be sustained in the framework of Protestantism (Nelson, 1965, 71; Nelson, 1981, 43-49). Whereas earlier medieval society made perfection the supreme goal, the Protestant accepted external restraints while seeking internal freedom. Independence, discipline, self-determination, and self-reliance were exemplary qualities of a Protestant. Those who had doubts about their ability, faith, and goodness suffered from anxiety, mental anguish, loneliness, and alienation. Those who felt lonely and alienated were treated in asylums. This method of treatment preceded modern advances in psychiatry and psychoanalysis (Rubin, 1979).

As nation-state building and bureaucracy replaced feudal and medieval society, the importance of memoria declined. Power had to be exercised in an impersonal and rule-bound manner. "As life became more calculable, emotion became more restrained," noted Evans (1996, p. 13) in his book on capital punishment in Germany. The state had become responsible for managing force, whereas civilians mimicked the example of the power elite and acted "civilly," rather than socially composing their own "rules of conscience." Considering the 17th and 18th centuries from a political and cultural perspective, Elias (2000), who lived from 1897 to 1990, examined the construction of civilized behavior developing in Europe's elite. Formalized manners and privatization of bodily habits signaled the internalization of restraint in matters of emotion. Such was the social outcome of a chaotic, turbulent, and violent transition from medieval times to capitalist nation-state building. Modernity and the new urban lifestyle required compromise, diplomacy, and the sublimation of emotions. Foucault (1975/1995) and Elias studied the relationship of state building to punishment and found that calculated and bureaucratically arranged punishments replaced public displays of violent impulses. Evans observed, "State stability and impersonal rule, giving rise to a process of 'conscience formation,' were thus two major factors in the "privatization of repression"” (p. 15).

Medieval notions about self-consciousness, casuistry, the Forum of Conscience, and the hierarchical schema for perfection were replaced by the individualized ethic of doing God's work in civilized, disciplined, orderly, and 
inwardly directed ways while living an ascetic lifestyle of lifelong repentance and "faith alone." According to Max Weber (1995), the Reformation and modernity reoriented social life in Old Europe while independent Protestants colonized the New World. Reformation and modernization highlighted the fact that individual memory and contemplation did not enable the individual subject to know the divine. The external conflicts of dualistic medieval life and belief systems became internalized in the insecure individual, alone in a world where spiritual perfection could not be obtained by following a system, demonstrated in jurisprudence, or bought for a price; indeed, one's spiritual salvation and direction was unknown, or known only to God.

\section{LEIBNIZ (1646-1716), BERGSON (1859-1941), THE METAPHYSICIANS ON MEMORY, PERSPECTIVE, AND KNOWLEDGE; NIETZSCHE (1844-1900) ON FORGETTING}

In 1686, Leibniz (1993) argued in his Discourse on Metaphysics that neither the individual nor society determine knowledge; he posited that perfect knowledge is God, and logic and mathematics are not superior to intuition. Leibniz also analyzed earlier concepts of how ideas and concepts are developed and retained, or not retained (pp. 68-72). Perceptions deliver expectations based on preceding associations and results based on prior related experience, Leibniz argued,

Men act in like manner as animals, in so far as the sequence of their perceptions is determined only by the law of memory, resembling the empirical physicians who practice simply, without any theory, and we are empiricists in three-fourths of our actions. (p. 257)

Memory is ultimately derived imperfectly from God or perfect knowledge; memory manifests in small changes (or perception) that originate ultimately in God, or pure knowledge, which is outside the human domain.

In 1714, Leibniz (1993) argued in the Monadology that

on awaking after a period of unconsciousness we become conscious of our perceptions, we must, without having been conscious of them, have had perceptions immediately before; for one perception can come in a natural way only from another perception, just as motion can come in a natural way only from a motion. (p. 256)

Leibniz did not exclude the idea of unconsciousness and included in his conceptualizations the idea of force, dynamism, action, and change or in his words, "what can happen to one corresponds to what happens to all others without their acting upon one another directly" (p. 70). Reasoning, according to Leibniz, was based on two principles: 
First, that of Contradiction, by means of which we decide that to be false which involves contradiction and that to be true which contradicts or is opposed to the false. ... And second, the principle of Sufficient Reason, in virtue of which we believe that no fact can be real or existing and statement true unless it has sufficient reason why it should be thus. (p. 258)

Leibniz (1993) also claimed there were two kinds of truths - truths of reasoning and truths of fact:

The truths of Reasoning are necessary and their opposite is impossible. Those of Fact, however, are contingent, and their opposite is possible. When truth is necessary, the reason can be found by analysis in resolving it into simpler truths until we reach those which are primary. (p. 258)

According to Leibniz's Monadology, individual entities or monads reflect imperfectly a small portion of this "indestructible universe." From the Leibnizian point of view, total knowledge is not known by society and change occurs by small degrees from within an entity which is "a multiplicity in the unity ... what is called Perception" (Leibniz, 1993, p. 253). Leibniz noted, "Apperception or Consciousness ... the Cartesians have fallen into a serious error, in that they treat as non-existent those perceptions of which we are not conscious" (p. 253).

Leibniz's (1993) Monadology abbreviates salient aspects of his grand theory of force, perception, knowledge, time, expectation, and God. Although Cartesian theory argued for mechanicalism and extension in response to the problematic theory of substantial forms, Leibniz posited a theory of dynamism to complete the Cartesian mechanical theory of res extensa, which translates as an extended substance. Leibniz argued that extension was only a frozen attribute (or present condition) with modifications in only position and time and with no reference to past or future and no explanation for changes from the original itself (p. viii). Leibniz's gradualist argument augmented the concept of using incremental time change studies to witness change but not explain it, because changes in the original came from within the original's own force or dynamism, which acted ultimately in preestablished harmony or from within passions originating in God (pp. XII-XIII). The Monadology and the Discourse on Metaphysics posit that something, which today we might call agency or solidarity, is attributable to a God or pure knowledge, is devoid of value judgments, and has qualities of what might be called "fate." The contradictions and nuances of Leibniz's philosophy have been the subject of much secondary research and are beyond the scope of this article. One condensed analysis of Leibniz's philosophy explains the many different approaches that Leibniz explored in his quest to improve on Cartesianism, commenting that "the principles held by Descartes and Leibniz were both correct, though different, and their conflict only apparent" (Kellogg, 1902, p. 421). Leibniz also considered the significance of forgetting and immortality (Leibniz 1951, p. 340). 
Friedrich Nietzsche was born 128 years after Leibniz's death. Nietzsche, like Leibniz, spent much of his life critiquing philosophical, scientific, cultural, and metaphysical social developments. Nietzsche's writings are colored by the effects of his lifetime struggles with illness and communicate powerfully a concern with the tenuousness of life, with "life" over and above science and historiography. The German thinker granted an indomitable significance to chaos even in a rational scientific world, studying the relationship between weakness (or illness) and power (or strength) and the importance of forgetting. Nietzsche compensated for his own lack of physical health by developing his mental capabilities, using his own experienced discrepancy between mental and physical as a lens for his writings. In an essay titled "On the Uses and Disadvantages of History for Life," Nietzsche (1874/1983) argued against the scientific rationalization of history:

Thus the historical sense makes its servants passive and retrospective; almost the only time the sufferer from the fever of history becomes active is when this sense is in abeyance through momentary forgetfulness - though even then, as soon as the act is finished he at once dissects it, prevents it from producing any further effects by analyzing it, and finally skins it for the purpose of "historical study." (p. 102)

Nietzsche (1874/1983) wrote that "a degree of sleeplessness, rumination and the historical sense ... is harmful and ultimately fatal to the living thing, whether this living thing be a man or a people or a culture" (p. 62). Nietzsche thought it good that people know when to forget and remember "at the right time" (p. 63) and that without the unhistorical moment, "man again ceases to exist and without that envelope of the unhistorical he would never have begun or dared to begin" (p. 64). He wrote that if history were used as a pure science, it would be a conclusion to life. History, Nietzsche observed, must be only an "attendant to life" that is "directed by a higher force, rather than used in the service of domination" (p. 67).

Nietzsche (1874/1983) saw benefits in social forgetfulness as a way to creativeness and freedom in a world derived again and again from "highly indirect knowledge of past ages and peoples, not from direct observation of life" (p. 118). He took seriously the concept of eternal return (there are a finite number of things and events, yet infinite time, so all combinations of things shall be repeated). The concept appears in Nietzsche's (1964) book Thus Spake Zarathustra, particularly in the fourth part. In his introduction to the book, D. Aiken (1964) discussed Nietzsche's tormented regard for "eternal recurrence." Rejecting the idea of evolution, or historical process, yet perplexed by the nagging question of how humans live fully for the present without the encumbrance of the past made Nietzsche "authentically a harbinger of existentialism" (Aiken, 1964, p. xv), although different from other existentialists and far more lonely. Aiken concluded that Nietzsche's categorical imperative is to live each moment as if one could will the moment to return. The idea of eternal return 
complements ideas about the healthiness of forgetting; the eternal return might hinder people who remembered all historical moments from enjoying the newness of life in the unhistorical present.

Born 173 years after Leibniz's death and 45 years after Nietzsche's birth, Henri Bergson was a French metaphysician who defined the place of metaphysical knowledge against the looming hegemony of scientific rationality developing in the early 1900s. Bergson posited individual memory as a living reality of the past that manifests itself in character and gives us awareness to guide our actions. Bergson's conception offered an epistemology of change linked to the individual's awareness and reflexivity. In the posthumously published book Creative Evolution, Bergson (1944) wrote, "This creation of self by itself is the more complete, the more one reasons on what one does" (p. 9) As such, scientific or mechanical explanations of change could not, Bergson argued, account for how our personality, "which is being built up each instant with its accumulated experience, changes without ceasing" (p. 9). Bergson wrote, "Awareness itself is a function of the possibility of choice, it is, in fact, sense of choice" (p. xiii). According to Bergson, choice and change came from within individuals themselves based on awareness of, and reflection on, past choices. Bergson's theory incorporates a conceptualization of agency as human choice based on memory and reflection of one's past and differs radically from Leibniz's theory of God or dynamism as the source of predetermined action.

In The Creative Mind, Bergson (1946) posited memory as a living reality of matter (material artifacts) and the "felt" past; the dead deposit or remnant trace of past actions or choices (p. xiii). Bergson hinted at a social construction of memory based in use value when he wrote,

In a word our present falls back into the past when we cease to attribute to it an immediate interest. What holds good for the present of individuals holds also for the present of nations: an event belongs to the past and enters into history when it is no longer of any direct interest to the politics of the day and can be neglected without the affairs of the country being affected by it. As long as its action makes itself felt, it adheres to the life of a nation and remains present to it. (p. 179)

Bergson argued that human action is dependent on the individual's past experiences. His arguments against Cartesian notions about time and action, as well as his use-value criterion for social remembering, are indicated in the following passage:

The brain serves to bring about this choice: it actualizes the useful memories; it keeps in the lower strata of the consciousness those which are of no use. One could say as much for perception. The auxiliary of action, it isolates that part of reality a whole that interests us; it shows us less the things themselves than the use we make of them. (p. 162) 
Bergson argued that the present emerges from a past that does not unfold like a fan but instead, flows continuously over subterranean wellsprings of memory. Bergson's theory relates notions of agency to personal memory along with what we now call the "unconscious."

Bergson (1946, p. 11-12) argued that science is the profession that can foresee because it can scientifically measure and extract the material world and events in it. Such capabilities made science seem more important because it appeared to have the facilities to help foresee and predict the future. Certainly commercial and capitalistic concepts and actions pertaining to such social things as the "latest fashions," "vogue," "fads," "old fashion," "out of date," "on time," "on schedule," "behind the times," "up to date," and "planned obsolescence" continue to validate capitalistic, rational, scientific, and mechanical enterprises in rendering the past inferior while justifying or promoting the superiority of new and scientifically improved products. Bergson's own theories fell victim to the effects of socially constructed time, becoming passé within his lifetime as they increased in complexity and decreased in popularity among a growing scientific community that rejected metaphysical discourse in favor of scientific method, laws, and rationality.

\section{CONSCIENCE AND MEMORY IN EARLY COMMON LAW AND SOVEREIGNTY}

Prior to the Middle Ages, societies in antiquity developed belief systems and cultural arrangements to manage the conscience of believers. During the Middle Ages, these techniques and practices became more complex, concentrated, and involved, culminating in an institution called the Forum of Conscience and the Tribunal of the Soul wherein church and state merged and focused on the conscience of subjects (Fifoot 1970, p. 301; Nelson, 1965, p. 63). Conscience was a foundation piece of medieval legal and sovereign concerns. Common law and social ethics followed from ideas of casuistry, such as "a simple promise was binding by its own intrinsic weight upon the conscience and that failure or refusal to keep it was a breach of a man's duty towards God" (Fifoot, 1970, p. 306). Casuistry was defined as an extension of the law of God through humanity's reason and morality, and it was applied equitably to new and unforeseen problems as discussed by Vinogradoff (1928) and Kirk (1927). Casuistry had a significant influence on English common law because it related to a person's obligation to God. This was problematic for those who did not believe in the God of the Christian Church, and such unbelievers were considered dangerous to church, state, and society. Even God-fearing Christians were conflicted by medieval moral casuistry when it arbitrarily encouraged the mercantile economy (including usury) while elaborately masking or explaining away the 
immorality of the practice in question (Hall, 1649, p. 2; Rubin, 1979; Trinkaus, 1955, p. 86).

Late in the 1700s, Pike and Hayward (1808) authored a casebook of conscience that contains a smaller essay titled "The Spiritual Companion or the Professing Christian Tried at the Bar of God's Word." This book is a record of answers to practical moral questions posed by "timorous Christians." It begins with a list of questions and then answers them in the form of a "case." Each case is a written record of a lecture presented in a series of community meetings. This book represents a kind of Christian manual for ethical living.

Another casebook of conscience, edited by Jeremy Taylor (1660), contains questions such as "Whether it be lawful for me to raise any profit by loan of money?" or "Whether is the seller bound to make known to the buyer the faults of that which he is about to sell?" The organization and structure of these books show a merger of religious moral codes and the beginnings of English case or common law. Book 3 of Taylor's casebook is concerned explicitly with the relationship between human and divine laws, specifically with the question of whether "human laws do directly bind the conscience," therefore, making it as great a sin to transgress human laws as laws of God. The equivocation required to eventually demonstrate the provisional identity of these two sets of laws required a kind of protolegal hairsplitting:

It is certain as an article of faith, as necessary as any other rule of manners, that being subject is bound to obey the just laws of his lawful superior, not only under fear of punishment from man, but under pain of divine displeasure. Because the power by which man make Laws is the power of God... This whole matter is infinitely demonstrated in this one consideration: The laws of man do certainly bind the conscience, that they have a power of limiting and declaring, and make the particulars to become the Laws of God. In Spain, if a wronged husband or father kill the apprehended adulterers, it is no murder; in England it is. (Taylor, 1660, pp. 429-430)

In the preface of Pike and Hayward's (1808) book, the authors explained that cases of conscience arise from the difficulties people have "within the course of their experience." Cases discussed in Joseph Hall's (1649) book address human behavior in areas as diverse as matrimony, piety, political liberty, fasting, clemency, oaths, and even apparel (including the question of "Whether may we not labor to cover a deformity in the body?"). Such cases seem to indicate that in this transitory period in history (when neither Church, kingdom, state, nor corporate enterprise, unilaterally, dominated culture), common people debated, thoughtfully and earnestly, among themselves about how to rationalize and conduct their own behavior. Pike and Hayward saw the purpose of the various rules listed in their book as facilitating practical activity. "And may the spirit of God," Pike and Hayward contended, "without whose peculiar blessing will attempt, will be ineffectual to answer any saving purposes making these a powerful means of 
bringing them nearer to Christ, and making them more lively and active in his service" (p. 233).

Memory itself became a vexed issue in these casebooks of conscience. For example, Christian subjects often wanted to remember their conversion experiences to verify that they were indeed children of God. Case XXVIII of Pike and Hayward's (1808) book opens with the query,

A person has had a religious education and can not remember at any time or place, when or where, God first wrought upon his soul; what judgment must he form of his state, and what methods must he take to be satisfied that he is a child of God? (p. 233)

Memory was critical to distinguish a time of grace from a time of sinning and provided a sort of legal or contractual verification of one's closeness to Christ:

It is true I have been sober from my youth, and I am not chargeable with any gross immoralities; my conversion could not therefore be so visible as that of the open and profane sinner, yet there is a great difference between mere morality and grace; and if good work is begun in me, whenever it was, the charge was great; and must I not remember some of the happy circumstances? (Pike \& Hayward, 1808, p. 233)

Pike and Hayward wrote that concerns such as these

are often a stumbling to the humble Christian, who cannot remember the time and circumstances of his conversion, and he is ready to fear that he is no more than an outward professor, and shall one day absolutely fall, and make it appear that he never received that grace of God in truth. (p. 234)

\section{MODERNITY: MARX (1818-1883) AND LUKÁCS (1885-1971)}

Martin Luther was the "liberator of conscience" until confronted with the end result of his liberation enterprise, which was neo-Platonic mysticism (as used in medieval meditation) integrated with Protestant illuminism. Then Luther reverted, wrote Nelson (1965), to the "medieval truism that conscientia (conscience) was meaningless without scientia (knowledge) ... this endorsement of medieval intellectualism was a blow against the unrestricted emancipation of the conscience from super personal norms" (p. 70). Marx's (1978) analysis of alienation stemming from commodity fetishism raises the issue of the commodity character of social life in the modern world. For Marx, the commodity simply provides one more historical example of human subjects' displacing their selfconsciousness onto external figures or objects. Having developed his analysis of alienation from his critique of Hegel's conception of history and spiritual selfknowledge, Marx saw in both religion and commodity fetishism a common 
term. Rather than human as spirit (as Hegel posited), Marx argued that spirit was ultimately humanity's self-realization of being alienated from a material world. In the "Economic and Philosophic Manuscripts of 1844," Marx first presented his famous theory about "Estranged Labor" and his "Critique of the Hegelian Dialectic and Philosophy as a Whole":

If I know religion as alienated human self-consciousness, then what I know in it as religion is not my self-consciousness, but my alienated self-consciousness confirmed in it. I therefore know my own self, the self-consciousness that belongs to its very nature, confirmed not in religion but rather in annihilated and superseded religion. (p. 119)

Religion could survive fitfully in a Weberian "disenchanted world," serving as a kind of psychic compensation for a capitalist order that despite its claims to "rationality," continued to conceal human relations in the form of autonomous commodities. Marx's attempts to grasp the capitalist mode of production as a historical phenomenon was in effect an attempt to "remember" a future in which capitalism would simply represent one more transitional stage of human selforganization on the way to communism.

Marx's (1978) comparative historical method introduced a valuable modern social scientific approach to perspective, consciousness, and social collective memory in a world preoccupied with material production, capitalist enterprise, and science. This is validated nicely in a recent interview with Eric Dunning of the Leicester School, who pointed out that his teacher, Norbert Elias, became convinced of the value of the comparative and historical method after newspapers reported that Britain was in crisis under the New Right and Thatcherism. Dunning commented,

He [Elias] reminded me of going into a café in 1923 and ordering a coffee for 20,000 marks, which had risen to 40,000 marks by the time he left. Money became valueless. Britain in the ' 80 's was nothing like that. In his view, this confirmed the value of the comparative and historical method of analysis. (Rojek, 2004, p. 353)

Marx was an economist, not a social psychologist; and whether he intended it or not-even in the ironic state of "valueless money"- his comparative historical method is invaluable for developing social perspective, discourse, and consciousness raising.

The accelerating commodification of every aspect of social life has recently encroached on the domain of social memory, for example, in the form of genetic material or electronic data banking. The historical record itself has become a strange sort of copyrightable hybrid of commodity and productive technology, which is a contested site among those who wish to control it. This new commodity can be viewed as a sort of congealed essence of labor capable of being absorbed into capital. According to Marxian analysis, the present-day mode of production contains remnants of past modes of production in which capital is 
simply the sediment traces of historical or "dead" labor power, which supposedly is never in labor's possession to begin with. In the case of DNA or sperm banking, the commodity is not the remnant of dead labor power but rather, the seed of potential labor power taken (often without compensation) from the bodies of laborers-not taken from their "labor power." The Marxian question that arises from such analysis is, "Where is, or what is, the value added in sperm banking, genetic engineering, seed banking, or digital surveillance?" Does "value added" arise from enhancement made to biological memory or "commodity memory product" or from the degradation of the original source of the commodity as it is destroyed by changing environmental conditions?

The various categories of Marxist analysis such as use and exchange value (Marx, 1978, p. 253) might be applied fruitfully to present-day marketing, production, and banking of congealed human and other biological material (such as seeds, sperm, or DNA) or electronic data files, but such application is beyond the scope of this article. It is important to emphasize that Marx's (1978) critique of commodity fetishism is roughly coextensive with his 1843 critique of organized religion generally:

Objectification is the practice of alienation. Just as man, so long as he is engrossed in religion, can only objectify his essence by an alien and fantastic being; so under the sway of egoistic need, he can only affirm himself and produce objects in practice by subordinating his products and his own activity to the domination of an alien entity, namely money. (p. 52)

This form of false consciousness, mistaking human relations as relations between things or between "fantastic" beings, was subsumed under the controversial Marxist category of "ideology." Human subjects, according to Marx (1978) in 1844, could not know themselves so long as they did not acknowledge the social character of production and exchange or the social determinants of religious thought as "the fantastic realization of the human being inasmuch as the human being possesses no true reality" (p. 54). Hence, without recourse to a more perfect world above or within, human salvation was to be found in revolution and a utopian, communist society. Because Marxism is secularized, this argument is still problematic to Marxists, for it appears to make revolution a mechanical reaction to economic conditions, dependent on an evolving proletarian class consciousness as detailed by Marx in 1848 .

As a Hungarian communist living in exile in Vienna in the mid-1920s, Georg Lukács took up this mechanistic view of revolutionary activity by examining why the proletariat, and no other class, was in a particularly privileged position to abolish class society. Lukács (1971/1985) acknowledged class consciousness had inevitable conflicting levels of agreement and disagreement within a total society. He recognized that people accepted and rejected in varying degrees their commodity labor status. This meant that workers did not always reject capitalist exploitation and did not always share the same consciousness at any given 
time. Holding such views was not a popular interpretation among communist orthodox Marxists of the 1920s and as such, Lukács's book History and Class Consciousness had been, in Lukács's estimation, misinterpreted by party authorities. Although Lukács publicly disavowed the book, he secretly wrote an involved rebuttal to its critics in 1925 or 1926, reiterating and clarifying his arguments. This manuscript, titled "Tailism and the Dialectic," remained hidden and unpublished until 1996 (Lukács's essay was published in English in 2000). Like the inquisitorial accounts uncovered by Ginzburg (1989/1992), Lukács's (2000) essay is an excellent example of the power of recorded historical narrative resurfacing at a "subjective" moment in history.

In Lukács's (2000) manuscript, he pointedly argued that the final outcome of the dialectical method, and commodity fetishism, was Lenin's theory of the party and Bolshevism. To avoid misunderstanding, he stated clearly that his book was concerned with the role of the party, particularly the notion of "imputed class consciousness," in the revolution. In Lukács's analysis, it was fundamental that there be a coordinating party making decisions that would direct the revolutionary process at a "subjective moment" (pp. 55-56).

As a Leninist, Lukács developed a dialectical theory of praxis that was not based on the more traditional idea of a separation of the working class and the state. The subjective moment of insurrection arises "exclusively in praxis" (Lukács, 2000, p. 56). Lukács (2000) asked, "How is it possible even to imagine Lenin's basic idea of the preparation and organization of revolution without such an active and conscious role of the subjective moment?" (p. 57). Hence, the coordinating party actively helps foster the consciousness of the proletariat and the conditions for insurrection. According to Lukács, insurrection requires a subjective moment of decision - a moment that is completely separate from the "objective," a moment when a decision can be made that will change the future direction of the revolutionary process (pp. 51, 55, 58); in other words, objective situations ripen into strategic subjective junctures (p. 57). And so, Lukács argued, revolutionary activity was not without an aesthetic component (p. 58).

Noteworthy is the acknowledgment in Lukács's (2000) "Tailism and the Dialectic" of "convenient" forgetting by leaders of "everything they offered the day before" and the emotional effect it has on "the masses" (p. 61). In fact, the above passage regarding the history of Lukács's suppressed manuscript demonstrates the advantage of material memory, stored and released at a subjective moment for wide readership.

\section{REFORMING CONSCIOUSNESS AND MEMORY IN A PRAGMATIC NEW WORLD}

In America, Protestant sects offered admission to church fellowship by following rigorous requirements of the "covenant of grace," leading to religious inner illumination and conversion, or sometimes leading to mental illness or a 
breakdown in the process (Rubin, 1979, pp. 44-90). Here the Church itself was a perfected enclave in which members were saved from the sinful outside world. Dualistic conceptualizations of good and evil, and of power and powerlessness, were constructed within the Church, the community, and the family, not as part of a totality incorporating the state, as an extension of nature, or as part of a plurality of social groupings. In religious settings that required perpetual self-control and constant scrutiny, there was little room for self-reflection or self-knowledge in the medieval conception of the words, for control (of oneself and by others) and rejection of the greater world and all its possibilities took precedence in Protestant sects. To engage in medieval rhetorical discourse about the nature of self-knowledge would have been blasphemous and dangerous because it would have caused doubt and guilt in the mind of the repentant. Protestants and Puritans engaged in torturous, ongoing self-examinations of their souls in an attempt to perpetually purify themselves of their sins and to have personal contact with God to serve his purpose pragmatically through correct action (Rubin, 1979, p. 8). One might wonder if the tortured survivors of the Inquisition, such as the Cathari or "Pure Ones," might have been converts to these sects in the New World. Jon Butler (1990) offered provocative and detailed analysis about the role of Christianity in early American society, politics, and capitalism (including slavery). American society has had the unusual capacity to ignore, as well as embrace, religion while also tolerating (and sometimes not) the development of an array of creative and original religious sects.

Among the changes brought by the Reformation was the reduction of memory practices. Books were plentiful and portable, so lessons and scripture did not have to be memorized. Pedagogy changed as educational institutions, busy civilizing urban youth and preparing future workers, could not afford to teach in an intimate, rhetorical question-answer dialogue between teacher and student as had been practiced in the medieval universities. Rather than learning to remember a verbal, changing dialogue (one not written and not repeated) that like a mental chess match, required memoria and mnemonics, students of modern educational institutions had little need for medieval contemplation on nature and dialectics. Newly emigrated Americans built new cities with names such as Rome, Ithaca, Syracuse, and Utica and in this pragmatic way, celebrated ancestral giants of the Old World by reconstructing them to fulfill the insecure needs of the New World.

\section{DURKHEIM AND SOCIAL CONSCIOUSNESS, HALBWACHS AND THE SOCIAL CONSTRUCTION OF MEMORY}

Emile Durkheim, like his teacher Comte, attributed a hierarchy to the human world. Durkheim devoted a lifetime to investigating categories of "social facts" and establishing sociology as a science. He sought to find the division of the sacred and profane in a totalized society, arguing that consciousness was social 
and that social consciousness was critical to human progress. Similarly, he argued that morality was ultimately an instantiation of this very social consciousness. Thus, individual morality, as a product of an underlying collective consciousness, bound society together in a profane world (Durkheim, 1912/ 1995, p. 224).

According to Durkheim (1912/1995), to aspire to a perfect society of truth, justice, and beauty was only a "desire rooted within the depths of man" because in a profane world, nothing outside of humanity could obviously account for such aspirations; striving for a perfect society "was an idea that expresses itself in consciousness of our more or less obscure aspirations toward the good" ( $p$. 423). For Durkheim, consciousness was an external expression of a person's desire for the good, and this desire multiplied in society was the social force behind the civilizing, historical, progress. Moving toward a more ideal society required collective action by which society could realize its position and its active cooperation (Durkheim, 1912/1973, p. 191). If collective action was promoted to the point of effervescence, people would experience a world to which they could attribute a higher dignity. From this dual perspective, people could witness an ideal world through collective action and effervescence (Durkheim, 1912/1973, p. 195; Durkheim, 1912/1995, p. 233).

In Durkheim's (1912/1995) analysis, individual consciousness is really only part of larger social consciousness: "If collective consciousness is to appear a sui generis synthesis of individual consciousness must occur" (p. 426). According to Durkheim (1915/1965), a person left alone to his or her own perceptions would not be a social being and therefore would be "indistinguishable from the beasts" (p. 487). Self-affirmation was released through ritual activity and mythological thought (Durkheim, 1912/1995, p. 426), which by their very nature was totalizing:

This idea of the all which is at the basis of the classifications which we have just cited could not have come from the individual, himself, who is only a part in relation to the whole and who never attains more than an infinitesimal fraction of reality. And yet there is perhaps no other category of greater importance; for as the role of the categories is to envelope all the other concepts, the category par excellence would seem to be this very concept of totality. The theorists of knowledge ordinarily postulate it as if it came of itself, while it really surpasses the contents of each individual consciousness taken alone to an infinite degree. (Durkheim, 1915/ 1965, p. 489)

Although Durkheim's (1915/1965) analysis assumed a totality, it also assumed that individual consciousness was divided and that a person's soul was divided as well. Because individuals have something impersonal in them, so too they possess an inevitable social instinct (Durkheim, 1912/1995, p. 447). Durkheim (1912/1973) cited Pascal's formula that the human is both "angel and beast," and yet it is exactly this "perpetual division against ourselves" that elevates humankind above and distinguishes humans from other beings (p. 154). 
Durkheim (1915/1965, p. 494; 1912/1995, p. 447) ventured that humans live antagonistic lives because of the biblical Fall. Ultimately, he claimed that the individual was a duality of the sacred and the profane.

Maurice Halbwachs joined the Durkheim school as a statistician, but he devoted much effort and writing to the examination of collective memory. After studying with Bergson, Halbwachs joined with the social scientists and had some interest in refuting Bergson's teachings. Halbwachs's writings on memory were published in English posthumously and titled The Collective Memory (1950/1980) and On Collective Memory (1952/1992). In these works, he asserted that memory and consciousness formed a sort of dyad from an early point in sociology. Halbwachs maintained the Durkheimian position that all memory was social memory and society determines what is important to remember, underscoring the fact that memory was an acknowledged aspect of consciousness. Halbwachs was interested in perception, and his ideas could have been inspired by Mead, although Mead (unlike Halbwachs) favored Bergson's work.

Traumatic memories and dreams were problematic for Halbwachs because they could not be corroborated. Individuals could not escape from themselves except by responding to others-not through dreams, art, or meditation (Halbwachs, 1952/1992, p. 44). Yet memory was liberating, Halbwachs (1952/ 1992 , p. 50) argued, because it gave us the illusion of not always being imprisoned by groups. Although Durkheim's dualistic, collective, totality concept does not accommodate conflict any more than it relinquishes its sacred/profane duality, Durkheim and Halbwachs together staked an important claim for sociology to explore the social construction of consciousness and memory-inheriting this project from the vanishing metaphysicians of the past and sharing the project with future generations of psychologists and sociologists.

\section{CONCLUDING THOUGHTS}

This article discusses the role of human memory in the social construction of self-knowledge in early European and American history. Medieval society used human memory as a source of knowledge and a conscious practice to advance moral and conscientious behavior in a time of turbulent change when the state, and its attendant forms of civil behavior, was not well developed. Medieval subjects could aspire to perfect themselves in a dualistic (Manichean-Gnostic) social context that viewed being and "activity" as virtuous and the opposite as evil. Contradictions within this faith-based dualistic belief system contributed to the onslaught of secularization, the Inquisition, and the Reformation.

Martin Luther and Protestant sects promoted an ascetic and independent lifestyle that turned faith inward, away from a profane world. The development of modern, urban capitalism required the religious changes brought about by the Reformation. The socially constructed moral guidelines of medieval society 
(meditation, casuistry, rhetoric) were replaced with civil behavior, privatization of emotion, a calculating lifestyle, state monopoly of force, and scientific rationality. Self-knowledge, morality, and consciousness in the modern nation-state of Marx's time became the subject of social scientific exploration and exploitation. Today, in a time of both "globalization" and corporate monopoly of major information sources, we are indebted to Marx's (1978) historical comparative method because it helps us think critically about corporate commodity memory presented as truth but sometimes experienced as incongruent with our lived experience or social remembrances.

According to sociology's own "rules of remembrance," theories of metaphysicians fall outside the cannon; however, the theories of metaphysicians such as Leibniz and Bergson influenced sociologists Halbwachs and Mead-particularly pertaining to ideas about memory. As a young man, Halbwachs studied with Bergson, but he became disappointed with Bergson's teachings. Halbwachs later wrote one of his dissertations on Leibniz after which he joined with the Durkheim school; and in the early 1900s, he wrote The Social Frameworks of Memory. These works have been translated and are presented in Halbwachs's (1952/1992) On Collective Memory. Halbwachs's ideas about collective memory radically refuted Bergson's popular ideas about the important role of individual memory. Halbwachs defended his radical ideas about collective memory in papers written after The Social Frameworks of Memory. These later writings were collected and published in 1950 in French in a book titled $\mathrm{La}$ Memorire Collective, which was then translated into English and published with an introduction by the cultural anthropologist Mary Douglas (1950/1980). In her introduction, Douglas noted that Halbwachs's synthesis on collective memory "contains criticisms of Bergsonism with support from Leibniz" (p. 17).

American sociologist George Herbert Mead appreciated Bergson's theories. According to John Dewey's (1959, p. viii) preface to Mead's The Philosophy of the Present (a book that highlights Mead's last work on perception), Mead was reading Bergson's Durée et Simultanéité the week before his death. Like Leibniz and Bergson, Mead was interested in finding new ways to explain perception, but he wanted to incorporate biological science, social sciences, statistics, and a concept of individual agency to derive a theory of the present. Unfortunately, Mead's theories were not well developed before his untimely death. What is recorded of these theories was gleaned from conference notes that he wrote for the Carus Lectures as read at the Meeting of the American Philosophical Association conference at the University of California-Berkeley in December 1930 and presented in Mead's (1959) The Philosophy of the Present.

In establishing sociology as a science, Durkheim also laid claim to the study of the social construction of memory. Through Halbwachs's work, sociology inherited the study of memory as a social phenomenon that is experienced individually and collectively. This historical discussion leaves out important contemporary debates regarding self-knowledge and memory, consciousness and emotion, and jurisprudence and the state. For example, truth-and-reconciliation 
commissions are condoned junctures of state, religious, and civil discourse on the legal and moral ramifications of human rights abuses. The public grievances of survivors of human rights abuses (often perpetrated by the state) present an interesting intellectual contrast to the forced confessions of heretics during the Inquisition. Although these two scenarios differ, they share common themes related to human memory, emotion, and political discourse. In conclusion, this article offers one interpretation of the role of memory in historical conceptualizations of self-knowledge and consciousnesses.

\section{REFERENCES}

Aiken, D. (1964). Introduction. In F. Nietzsche, Thus spake Zarathustra (T. Common, Trans., pp. xiv-xv). New York: Thistle Press.

Bergson, H. (1944). Creative evolution (A. Mitchell, Trans.). New York: Random House.

Bergson, H. (1946). The creative mind (M. L. Andison, Trans.) New York: Philosophical Library.

Butler, J. (1990). Awash in a sea offaith: Christianizing the American people. Cambridge, MA: Harvard University Press.

Carruthers, M. (1996). The book of memory: A study of memory in medieval culture. New York: Cambridge University Press. (Original work published 1990)

Dewey, J. (1959). Preface. In G. H. Mead, The philosophy of the present (A. E. Murphy, Ed., pp. viiviii). La Salle, IL: Open Court.

Douglas, M. (1980). Introduction. In M. Halbwachs The collective memory (F. J. Ditter \& V.-Y. Ditter, Trans., pp. 1-21). New York: Harper Colophon Books. (Original work published 1950)

Durkheim, E. (1965). The elementary forms of the religious life (J. W. Swain, Trans). New York: Free Press. (Original work published 1915)

Durkheim, E. (1973). Emile Durkheim on morality and society: Selected writings (R. Bellah, Ed.). Chicago: University of Chicago Press. (Original work published 1912)

Durkheim, E. (1995). The elementary forms of the religious life (K. E. Fields, Trans.). New York: Free Press. (Original work published 1912)

Elias, N. (2000). The civilizing process: Sociogenetic and psychogenetic investigations (E. Jephcott, Trans., Rev. ed.). Cambridge, MA: Blackwell.

Evans, R. J. (1996). Rituals of retribution: Capital punishment in Germany, 1600-1987. New York: Oxford University Press.

Fifoot, C. H. S. (1970). History and sources of common law-tort and contract. Westport, CT: Greenwood.

Foucault, M. (1995). Discipline and punish: The birth of the prison (A. Sheridan, Trans.). New York: Vintage. (Original work published 1975)

Ginzburg, C. (1981). Anthropology and history in the 1980s: A comment. Journal of Interdisciplinary History, 12, 277-278.

Ginzburg, C. (1992). Ecstasies: Deciphering the witches'Sabbath (R. Rosenthal, Trans.). New York: Penguin. (Original work published 1989)

Halbwachs, M. (1980). The collective memory (F. J. Ditter \& V.-Y. Ditter, Trans.). New York: Harper Colophon Books. (Original work published 1950)

Halbwachs, M. (1992). On collective memory (L. A. Cosner, Trans.). Chicago: University of Chicago Press. (Original work published 1952)

Hall, J. (1649). Resolutions and decisions of divers practical cases of conscience in continual use amongst men. London: A. Roper \& J. Sweeting.

Kellogg, D. D. (Ed.). (1902). Encyclopaedia Britannica (20th-century ed., Vol. XIV). New York: Werner. 
Kirk, K. E. (1927). Conscience and its problems: An introduction to casuistry. New York: Longmans, Green.

Leibniz, G. W. (1951). XXXIV. Concerning the difference between spirits and other substances, souls or substantial forms; that the immortality which men desire includes memory. In P. P. Wiener (Ed.), Leibniz selections (pp. 339-340). New York: Scribner.

Leibniz, G. W. (1993). Discourse on metaphysics, Correspondence with Arnauld, Monadology. New York: Open Court.

Lukács, G. (1985). History and class consciousness: Studies in Marxist dialectics (R. Livingstone, Trans). Cambridge, MA: MIT Press. (Original work published 1971)

Lukács, G. (2000). A defence of history and class consciousness: Tailism and the dialectic (J. Rees, Trans). New York: Verso.

Marx, K. (1978). The Marx-Engels reader (R. Tucker, Ed., 2nd ed.). New York: Norton.

Mead, G. H. (1959). The philosophy of the present (A. E. Murphy, Ed.). La Salle, IL: Open Court.

Nelson, B. (1965). The quest for self-control: Classical philosophies and scientific research (S. Z. Klausner, Ed.). New York: Free Press.

Nelson, B. (1981). On the roads to modernity: Conscience, science and civilizations: Selected writings (T. E. Huff, Ed.). Totowa, NJ: Rowman \& Littlefield.

Nietzsche, F. (1964). Thus spake Zarathustra (T. Common, Trans.). New York: Thistle Press.

Nietzsche, F. (1983). On the uses and disadvantages of history for life (1874) (R. J. Hollingdale, Trans). In Untimely meditations (pp. 59-123). New York: Cambridge University Press. (Original work published 1874)

Pike, S., \& Hayward, S. (1808). Religious cases of conscience answered in an evangelical manner at the casuistical lecture [Micro-print] (Early American Imprints, 2nd Series, No. 15,952). Portsmouth, NH: Treadwell for Peirce.

Phillips, D. (1955). The way to religious perfection according to St. Bonaventure's De triplici via. In J. H. Mundy, R. W. Emery, \& B. Nelson (Eds.), Essays in medieval life and thought (pp. 31-58). New York: Columbia University Press.

Piltz, A. (1981). The world of medieval learning (D. Jones, Trans.). Totowa, NJ: Barnes \& Noble.

Rojeck, C. (2004). An anatomy of the Leicester School of Sociology: An interview with Eric Dunning. Journal of Classical Sociology, 4(3), 337-359.

Rubin, J. (1979). Mental illness in early nineteenth century New England and the beginnings of institutional psychiatry as revealed in a sociological study of The Hartford Retreat, 1824-1843. Unpublished doctoral dissertation, Graduate Faculty of Political and Social Research, New School University, New York.

Sider, G., \& Smith, G. (1997). Introduction. In G. Sider \& G. Smith (Eds.), Between history and histories: The making of silences and commemorations (pp. 1-28). Toronto, Ontario, Canada: University of Toronto Press.

Taylor, J. (1660). Doctor dubitantium: Or the rule of conscience in all her general measures. London: J. L. for Luke Meredite MDCXCVI.

Trinkaus, C. (1955). The religious foundations of Luther's social views. In J. H. Mundy, R. W. Emery, \& B. Nelson (Eds.), Essays in medieval life and thought (pp. 73-87). New York: Columbia University Press.

Vinogradoff, P. (1928). The collected papers of Paul Vinogradoff. Oxford, UK: Clarendon.

Weber, M. (1995). The Protestant ethic and the spirit of capitalism. London: Routledge.

Yates, F. (1974). The art of memory. Chicago: University of Chicago Press. (Original work published 1966)

Yates, F. (1991). Giordano Bruno and the hermetic tradition. Chicago: University of Chicago Press. (Original work published 1964)

NOEL PACKARD is a graduate student in the Sociology Department of New School University, Graduate Faculty, New York. She has a bachelor's degree in economics from California State University, Fresno, a master's degree in public administration from California State 
University, Hayward (recently renamed California State University, East Bay), and a master's degree in sociology from New School University. She hosts a panel session for the annual meeting of the Pacific Sociological Association titled "Sociology of Memory: Personal or Commodity, Public or Private?"

CHISTOPHER CHEN is a Ph.D. candidate in the Department of English at University of California, Berkeley and is writing his dissertation on objectivist poetics and Marxist cultural theory. 